\title{
HYPERTROPHIC INFUNDIBULAR STENOSIS COMPLICATING SIMPLE PULMONARY VALVE STENOSIS
}

\author{
BY
}

\author{
A. M. JOHNSON \\ From the Cardiac Department, Guy's Hospital \\ Received January 18, 1959
}

Pulmonary valvotomy by the closed transventricular technique was introduced as an alternative to the Blalock-Taussig operation in Fallot's tetralogy (Brock, 1948) and for relief of pulmonary stenosis in the presence of a closed ventricular septum (Brock and Campbell, 1950). In Fallot's tetralogy, at least until closure of the ventricular septal defect became feasible, some residual pulmonary stenosis was considered desirable. With a normal aortic root, however, complete relief of the stenosis was sought. It was soon found that this could not always be achieved at operation and for this three main reasons have been suggested.

Kirklin et al. (1953), reporting twelve cases of transventricular pulmonary valvotomy, discussed the possibility that right ventricular hypertrophy might result in secondary stenosis in the infundibular region. Brock (1955), in an account of control mechanisms in the outflow tract of the right ventricle following a careful study extending over seven years, described and illustrated with pressure records secondary infundibular stenosis after pulmonary valvotomy. He discussed two factors responsible for this, the first mechanical, particularly in the region of the greatly enlarged crista supraventricularis, the second an exaggeration of the infundibular muscle tonus that normally functions to support the pulmonary valve ring. He suggested that, when this condition prevented complete relief of right ventricular hypertension, even a partial relief might suffice to allow regression of right ventricular hypertrophy and thus of secondary infundibular obstruction.

Comparing their results of transventricular pulmonary valvotomy and of the open procedure Swan et al. (1954) expressed the view that inadequate valvotomy was the usual cause of failure to reduce right ventricular pressure with the closed technique. They contrasted the complete relief obtained in every one of five open operations in which they performed pulmonary valvotomy through the pulmonary artery, using hypothermia, and concluded that hypertrophy of the right ventricle was not a cause of outflow obstruction. The same group, however, found later that open valvotomy did not always completely remove the systolic gradient between right ventricle and pulmonary artery (Blount et al., 1957) and agreed that this was sometimes due to infundibular obstruction which, they observed, was capable of regression. Campbell and Brock (1955) suggested a third explanation of residual stenosis, namely that the valve ring itself and the outflow tract were small. They noted that, in spite of a high residual gradient following valvotomy, the clinical improvement and the diminution of right ventricular strain were better than they had expected. In one such case the right ventricular pressure was found to have fallen further at recatheterization a year after operation.

McGoon and Kirklin (1958) have reported further experience with transventricular and open pulmonary valvotomy. They found that, in some patients, infundibular stenosis demonstrated by catheterization within a few weeks of operation had regressed completely twelve to eighteen months later. The existence of infundibular obstruction after valvotomy appeared to add to the hazards of the post-operative period. 
Engle et al. (1958) reported regression of hypertrophic infundibular stenosis in three cases within a year of open pulmonary valvotomy: they considered these results implied that "it is unnecessary to resect portions of the right ventricular outflow tract under these circumstances". Not everyone agrees with this view at present. Lillehei (1958) has suggested that any surgical technique for the relief of pulmonary stenosis must allow of ventriculotomy for infundibular resection should severe infundibular obstruction be revealed after valvotomy. The matter remains controversial regarding both the question of infundibular muscle resection and the degree of regression with the passage of time.

The present study was designed to determine the incidence of hypertrophic infundibular stenosis and its immediate and remote prognosis, after valvotomy.

\section{MATERIAL AND Methods}

Seventy-five cases of pulmonary valve stenosis with closed ventricular septum, operated upon by Sir Russell Brock at Guy's Hospital between June 1950 and June 1958, have been reviewed. Fifty-six had closed transventricular valvotomy and in three of these closed infundibular resection was also carried out. Nineteen had open valvotomy through the pulmonary artery, seventeen with hypothermia and two with heart-lung-bypass extracorporeal circulation. Open infundibular resection was performed in five of the hypothermia cases.

Pre-operative cardiac catheterization data, with the pressure tracings, were examined in 55 cases. Pressure records were made at operation before and after valvotomy in 66 cases. In two others, postvalvotomy records only were obtained. Post-operative catheterization was performed in 26 cases, the shortest interval after operation being three months and the longest nearly seven years.

Eleven cases who had shown infundibular obstruction following pulmonary valvotomy were selected for more detailed studies.

Clinical features were obtained from the patients' records and the eleven selected cases were personally examined at the time of recatheterization. Electrocardiograms were all recorded on a Sanborn directwriter and were thus easily compared over the years. Phonocardiograms were obtained through N.E.P. amplifiers and multichannel photographic recording apparatus.

Pressure records were made at cardiac catheterization and at operation, using Southern Instruments capacitance manometers and amplifiers, with twin-channel Brush direct-writing recorder except in the eleven selected cases for which N.E.P. photographic recording was used. At operation withdrawal pressure records were made from pulmonary artery to right ventricle, before and after valvotomy, by means of a cannula introduced through the wall of the right ventricle. Following open valvotomy a finger was passed from the pulmonary artery down into the right ventricle to exclude associated congenital infundibular stenosis.

The selected cases were recatheterized using a double-lumen catheter to obtain simultaneous, supermposed pulmonary arterial and right ventricular pressures during rest and exercise. By use of the proximal aperture, repeated withdrawal records from pulmonary artery to right ventricle were obtained free from ectopic beats. In this way detailed records of pulmonary arterial, infundibular, and right ventricular pressures were obtained with simultaneous electro- and phono-cardiograms. Systemic arterial pressure was also recorded from an indwelling Cournand needle (18 gauge) in the brachial artery.

Cardiac output was estimated by the Fick method, using the air-filled Donald-Christie (1949) closed circuit spirometer, with simultaneous pulmonary and brachial arterial blood samples, at rest and during exercise. The latter consisted of pedalling against a constant load, and five to seven minutes were allowed for a steady state to be established during it.

\section{RESULTS}

Nature of the Obstruction. Direct observation at ventriculotomy in three cases and at autopsy in seven has confirmed that this obstruction is produced purely by muscle hypertrophy in the outflow tract as part of general right ventricular hypertrophy. In one case only was slight endocardial thickening found in the outflow tract. The anatomical mechanisms have recently been fully reviewed by Brock (1957).

Four of these cases had shown before valvotomy infundibular systolic gradients that increased after it.

Incidence. For reasons that will be discussed in a separate report of pressure wave forms in pulmonary stenosis, an infundibular systolic gradient of over $20 \mathrm{~mm}$. $\mathrm{Hg}$ is taken to indicate hæmodynamically significant infundibular stenosis. 
Infundibular stenosis, so defined, was present in 17 per cent before valvotomy and in these cases it was increased following the valvotomy. It was demonstrated for the first time after valvotomy in 35 per cent when this was by the closed technique and in 59 per cent when it was by an open technique. Thus, overall, 51 per cent in the closed and 77 per cent in the open valvotomy group showed significant infundibular obstruction (Table I).

TABLE I

INCIDENCE OF SECONDARY INFUNDIBULAR STENOSIS

\begin{tabular}{|c|c|c|c|c|}
\hline & & Total & $\begin{array}{c}\text { Closed } \\
\text { valvotomy }\end{array}$ & $\begin{array}{c}\text { Open } \\
\text { valvotomy }\end{array}$ \\
\hline $\begin{array}{l}\text { Operated cases } \\
\text { Infundibular stenosis before valvotomy } \\
\text { Infundibular stenosis after valvotomy } \\
\text { Total with infundibular stenosis ... }\end{array}$ & $\begin{array}{l}. . \\
\cdots \\
\cdots\end{array}$ & $\begin{array}{l}66 \\
11(17 \%) \\
27(41 \%) \\
38(58 \%)\end{array}$ & $\begin{array}{l}49 \\
8(16 \%) \\
17(35 \%) \\
25(51 \%)\end{array}$ & $\begin{array}{l}17 \\
3(18 \%) \\
10(59 \%) \\
13(77 \%)\end{array}$ \\
\hline
\end{tabular}

In seeking criteria by which the supervention of infundibular stenosis following pulmonary valvotomy might be predicted, age, right ventricular systolic pressure, the electrocardiogram, and the cardiothoracic ratio were considered.

With increasing age there was a steady increase in the proportion of cases showing infundibular stenosis. In the first decade 10 of $15(66 \%)$ showed it; in the second decade 23 of $31(74 \%)$; and in the third decade 11 of 13 cases $(85 \%)$.

It is generally agreed that this complication does not occur in mild cases of pulmonary valve stenosis. Average right ventricular systolic pressure at pre-operative cardiac catheterization was $155 \mathrm{~mm}$. $\mathrm{Hg}$, with extremes of 109 and $238 \mathrm{~mm}$., in the group with infundibular stenosis; and $125 \mathrm{~mm}$., with extremes of 77 and $190 \mathrm{~mm}$.; in the group without it.

In the electrocardiograms, the mean height of the $R$ wave in lead V1 was $28 \mathrm{~mm}$. in the group with infundibular stenosis and $16 \mathrm{~mm}$. in the group without it. - The proportion of cases showing infundibular stenosis rose with increasing severity of cardiographic changes, whether R-wave voltage in V1 or T-wave inversion in leads V1, 2 and 3 was the criterion used (Fig. 1). The cardiothoracic ratio was unhelpful, the average in the group with infundibular stenosis being 51 per cent (extremes $39 \%$ and $67 \%$ ) compared with 56 per cent in the other group (extremes $35 \%$ and $69 \%$ ).

Thus, the older the patient and the more severe the electrocardiographic changes and the right ventricular hypertension, the more likely is secondary infundibular stenosis to occur.

The severity of the obstruction at the infundibular site, after valvotomy, was related to the height of the preoperative right ventricular systolic pressure (Fig. 3).

\section{Immediate Post-operative Prognosis}

This appeared to bear some relation to the right ventricular systolic pressure immediately following the operative procedure, whether this was valvotomy alone or accompanied by infundibular resection. A right ventricular systolic pressure about $100 \mathrm{~mm}$. $\mathrm{Hg}$ seemed critical (Table II). Six of ten patients in whom it was higher than this showed persistent systemic hypotension and evidence of right ventricular failure. Two of them died about a day after operation.

On the other hand, of 58 patients whose pressure was reduced below $100 \mathrm{~mm}$. $\mathrm{Hg}$, only four showed congestive heart failure post-operatively and all these recovered. Six post-operative deaths occurred in this group but in none of these were the features of right ventricular obstruction evident. Two were attributable to arrhythmias, prolonged and repeated ventricular fibrillation during operation in one and intractable ventricular tachycardia after operation in the other. A thirteenyear-old girl died with "post-perfusion cerebral syndrome". A man, aged 37, whose right ventricular systolic pressure was reduced from 120 to $38 \mathrm{~mm}$. by closed valvotomy, without the appearance of infundibular stenosis, died suddenly twenty-four hours later: autopsy revealed a grossly 
fibrotic and dilated right ventricle. In a girl, aged 12, closed pulmonary valvotomy had reduced right ventricular pressure from 173 to $113 \mathrm{~mm}$. and closed infundibular resection then reduced it to $42 \mathrm{~mm}$.: heart block and a small communication between the ventricles resulted, however, and must have contributed to the fatal outcome. The sixth death was in the case of a man aged 20, in whom pulmonary valvotomy had been attempted unsuccessfully elsewhere two years previously: his right ventricular pressure before valvotomy was $160 \mathrm{~mm}$. $\mathrm{Hg}$ and there were valvar and infundibular gradients. Following open valvotomy there was evidence of severe infundibular obstruction, so after ventriculotomy, infundibular resection was carried out: finally, pulmonary arterial pressure was $20 / 8$ and right ventricular $56 / 4 \mathrm{~mm}$., with systolic gradients of $8 \mathrm{~mm}$. at the 


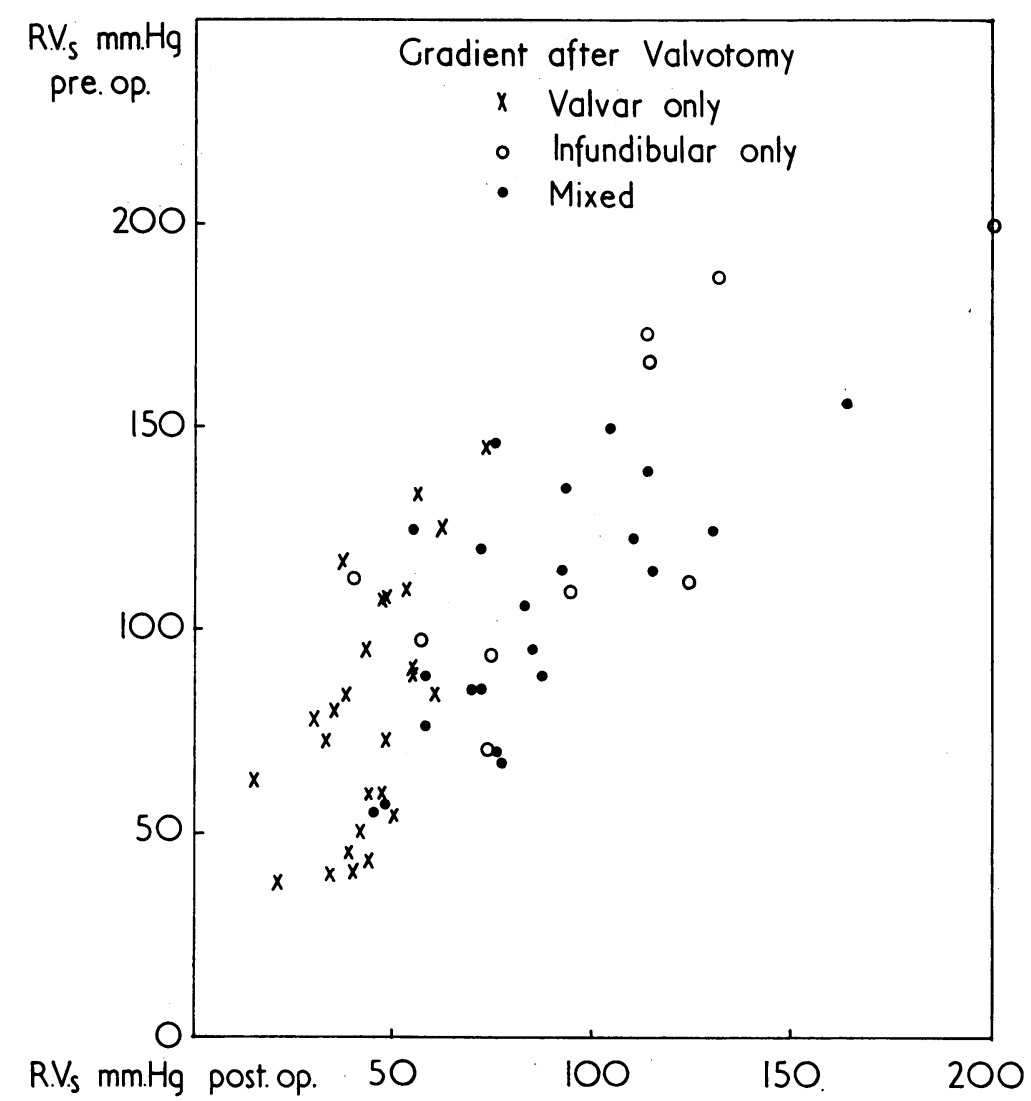

FIG. 3.-Relationship of right ventricular systolic pressures immediately before and after valvotomy. The higher the R.V. systolic pressure before operation, the more severe is the residual stenosis after valvotomy and this is predominantly or wholly at infundibular level.

valve and $28 \mathrm{~mm}$. in the infundibulum. Twelve hours later, after an initially untroubled postoperative course, he died of uncontrollable intrathoracic hæmorrhage apparently associated with the division of multiple adhesions which had resulted from the previous operation.

Infundibular resection was performed eight times in the present series (Table II), in three cases by the closed technique and in five by ventriculotomy. In a boy aged 4 , whose right ventricular systolic pressure had not been reduced by open valvotomy, open infundibular resection brought it from 200 to $120 \mathrm{~mm}$. $\mathrm{Hg}$ : he died twenty-four hours later in congestive heart failure. In two cases, right ventricular systolic pressures well over $100 \mathrm{~mm}$. following valvotomy were reduced below this by infundibular resection with good recovery in both cases. In a child aged 5 and a girl aged 21 , open pulmonary valvotomy had brought the right ventricular systolic pressures below $100 \mathrm{~mm}$. and, although ventriculotomy and infundibular resection produced no further reduction in either case, they both made uneventful recoveries. The closed procedures in a girl, aged 30, had the same results and outcome.

\section{LONG-TeRm Prognosis After Operation}

The degree of regression of hypertrophic infundibular stenosis and the response of the heart to exercise after such regression have been studied in a selected group of eleven cases (Table III). All had shown infundibular obstruction after valvotomy with residual systolic gradients of $50 \mathrm{~mm}$. 
$\mathrm{Hg}$ or more at that time. One to seven years had elapsed since operation, with a mean of four years.

Assessment was (1) clinical, (2) electrocardiographic, (3) radiological, (4) phonocardiographic, and (5) hæmodynamic.

Clinical. These patients, whose disability consisted mainly of exertional dyspnœa (grade one to three out of four), have all done well subjectively and have normal or nearly normal exercise tolerance. The improvement was immediate in all except one, in whom there was continuing diminution of dyspnœa over a period of six months.

Some degree of right ventricular hypertrophy was still evident in them all as a left parasternal lift (grade one to two out of four). The pulmonary systolic murmur proved a useful guide to the degree of residual stenosis. Three cases had developed pulmonary diastolic murmurs since operation (Cases 7, 9, and 10, Table III).

A pathologically large $a$ wave in the jugular venous pulse, which all had before operation, was still present in two. In one of these (Case 6, Table III) severe pulmonary valve stenosis had been relieved one year before and moderate stenosis, greater at infundibular than at valvar level, remained. In the other, a girl aged 23 (Case 7, Table III), severe valvar stenosis had been relieved seven years before, leaving moderate stenosis almost entirely at infundibular level: she now showed very mild valvar stenosis only, but how long she had taken to regress from moderate to mild is unknown. The persistence of a large $a$ wave and marked cardiographic changes (Fig. 4) may suggest that the regression at infundibular level had not long been complete; but the presence of pulmonary regurgitation may have had some influence.

Electrocardiographic progress was shown best by R-wave voltage in lead V1. Cases with moderate or severe changes before operation have shown improvement while those with initially mild cardiographic signs showed little or no change (Fig. 2).

T-wave changes, as in the case mentioned above, are difficult to interpret. They have not, on the whole, improved in parallel with the $\mathbf{R}$ wave. It is thought that persistence of $\mathrm{T}$-wave inversion may, in some cases, be attributed to post-operative pericardial reaction with associated permanent epicardial changes', though in others it may be due to irreversible fibrotic changes in the muscle of the right ventricle. There are, of course, cases where the $\mathrm{T}$-wave and $\mathrm{R}$-wave regression occur together (Fig. 5, Case 10, Table III).

Radiologically the lung-fields in all cases have appeared better vascularized. The cardiothoracic ratio (Fig. 6) has diminished in those where it was initially high. An exception was Case 7 (Table III), whose cardiothoracic ratio was 54 per cent at operation and 56 per cent seven years after operation, despite virtually complete relief of stenosis, probably because of pulmonary regurgitation. In another case with pulmonary regurgitation the cardiothoracic ratio has remained unchanged $(51 \%)$ for three years. In a third the ratio has increased from 45 before to 49 per cent three years after. In all these cases stenosis has been almost completely relieved.

Hamodynamic Studies. Changes in right ventricular systolic pressure between operation (immediately after valvotomy) and the post-operative cardiac catheterization in these and eight other cases in whom the figures were available, are seen in Fig. 7. Of four residual pure valvar gradients two were unchanged, one had increased (presumably due to higher flow at the post-operative catheterization) and one had remained constant but was now accompanied by an infundibular gradient in addition. Where the post-valvotomy gradient was mixed (10 cases) or infundibular only ( 5 cases), the total gradient and thus the right ventricular systolic pressure, has shown a further fall since operation.

Eight of the eleven selected cases showed complete regression of infundibular stenosis despite some residual valve stenosis in four (mild in two, moderate in two). Three have shown incomplete regression. In two this was associated with moderate residual valve stenosis, one after one year, the other after four years (Cases 6 and 1, Table III). In the other (Case 11), twenty-one months had elapsed since complete relief of valve stenosis. All three of these cases survived right ventricular systolic pressures of over $100 \mathrm{~mm}$. Hg following pulmonary valvotomy, one with and two without post-operative right ventricular failure. 
TABLE III

Pressure and Flow Data in Eleven Cases with Secondary Infundibular Stenosis after Pulmonary Valvotomy

\begin{tabular}{|c|c|c|c|c|c|c|c|c|}
\hline $\begin{array}{l}\text { Case } \\
\text { No. }\end{array}$ & $\begin{array}{l}\text { Sex } \\
\text { and } \\
\text { age }\end{array}$ & $\begin{array}{l}\text { Years } \\
\text { after } \\
\text { op. }\end{array}$ & & & $\begin{array}{l}\text { R.V. syst. } \\
\text { pressure } \\
(\mathrm{mm} . \mathrm{Hg})\end{array}$ & $\begin{array}{c}\text { Valvar } \\
\text { systolic } \\
\text { gradient } \\
(\mathrm{mm} . \mathrm{Hg})\end{array}$ & $\begin{array}{l}\text { Infundib. } \\
\text { systolic } \\
\text { gradient } \\
(\mathrm{mm} . \mathrm{Hg})\end{array}$ & $\begin{array}{l}\text { Resting } \\
\text { cardiac } \\
\text { index } \\
\text { (1/min./ } \\
\text { sq. m.) }\end{array}$ \\
\hline$\left(\begin{array}{c}1 \\
(\mathrm{~V} 116)^{*}\end{array}\right.$ & M21 & 4 & $\begin{array}{l}\text { Preop. catheter } \\
\text { At operation: before valvotomy } \\
\text { " after valvotomy } \\
\text { Postop." catheter } \quad \text {.. } \quad . .\end{array}$ & $\begin{array}{l}\cdots \\
\cdots \\
\cdots \\
\cdots\end{array}$ & $\begin{array}{r}180 \\
140 \\
113 \\
55 \\
\end{array}$ & $\begin{array}{r}140 \\
101 \\
19 \\
10 \\
\end{array}$ & $\begin{array}{l}20 \\
30 \\
62 \\
29 \\
\end{array}$ & $\begin{array}{l}2 \cdot 3 \\
2 \cdot 9\end{array}$ \\
\hline $\begin{array}{c}2 \\
(V 134)\end{array}$ & M13 & 6 & 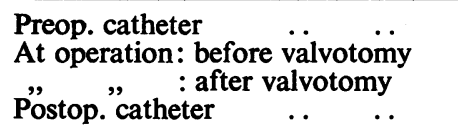 & $\begin{array}{l}. \\
\ddot{0} \\
\ddot{.}\end{array}$ & $\begin{array}{r}140 \\
95 \\
85 \\
65\end{array}$ & $\begin{array}{r}124 \\
77 \\
28 \\
35\end{array}$ & $\begin{array}{r}0 \\
0 \\
39 \\
8\end{array}$ & $\begin{array}{l}2 \cdot 9 \\
3 \cdot 1\end{array}$ \\
\hline $\begin{array}{c}3 \\
\text { (V120) }\end{array}$ & M19 & 4 & $\begin{array}{l}\text { Preop. catheter } \\
\text { At operation: before valvotomy } \\
\text { Postop." catheter } \quad \text { a a } \quad . \quad \ldots\end{array}$ & $\begin{array}{l}. \\
\therefore \\
. . \\
.\end{array}$ & $\begin{array}{r}157 \\
150 \\
100 \\
41\end{array}$ & $\begin{array}{r}145 \\
128 \\
13 \\
0\end{array}$ & $\begin{array}{r}0 \\
0 \\
67 \\
17\end{array}$ & $\begin{array}{l}3 \cdot 4 \\
2 \cdot 9\end{array}$ \\
\hline $\begin{array}{c}4 \\
(V 86)\end{array}$ & F14 & $5 \frac{1}{2}$ & $\begin{array}{l}\text { At operation: before valvotomy } \\
\text { Postop. catheter valvotomy } \\
\text { Poster } \quad \text {.. } \quad .\end{array}$ & $\begin{array}{l}\because \\
\ddot{.} \\
.\end{array}$ & $\begin{array}{r}106 \\
83 \\
58 \\
\end{array}$ & $\begin{array}{l}87 \\
11 \\
22 \\
\end{array}$ & $\begin{array}{r}0 \\
53 \\
17 \\
\end{array}$ & $4 \cdot 7$ \\
\hline $\begin{array}{c}5 \\
\text { (V78) }\end{array}$ & F7 & 6 & $\begin{array}{l}\text { At operation: before valvotomy } \\
\text { "” after valvotomy } \\
\text { Postop." catheter } \quad . . \quad \quad . .\end{array}$ & \begin{tabular}{l|}
$\because$ \\
$\therefore$ \\
.
\end{tabular} & $\begin{array}{r}109 \\
94 \\
42\end{array}$ & $\begin{array}{r}28 \\
0 \\
0\end{array}$ & $\begin{array}{l}67 \\
77 \\
18\end{array}$ & $4 \cdot 1$ \\
\hline-6 & M21 & 1 & $\begin{array}{l}\text { Preop. catheter } \\
\text { At operation: before valvotomy } \\
\text { "”stop." a catheter valvotomy } \\
\text { Poster } \quad \text {.. } \quad \text {.. }\end{array}$ & $\begin{array}{l}. . \\
\cdots \\
\cdots \\
.\end{array}$ & $\begin{array}{r}136 \\
156 \\
163 \\
97 \\
\end{array}$ & $\begin{array}{r}134 \\
57 \\
20 \\
\end{array}$ & $\begin{array}{r}0 \\
83 \\
43 \\
\end{array}$ & $\begin{array}{r}3 \cdot 9 \\
2 \cdot 5 \\
\end{array}$ \\
\hline $\begin{array}{c}7 \\
\text { (V69) }\end{array}$ & F17 & $6 \frac{3}{4}$ & $\begin{array}{l}\text { Preop. catheter } \\
\text { At operation: before valvotomy } \\
\text { \#”, after valvotomy } \\
\text { Postop. catheter } \quad \text {.. } \quad . .\end{array}$ & \begin{tabular}{l|}
.. \\
$\cdots$ \\
$\cdots$ \\
$\cdots$
\end{tabular} & $\begin{array}{r}140 \\
85 \\
70 \\
35\end{array}$ & $\begin{array}{r}128 \\
65 \\
12 \\
10\end{array}$ & $\begin{array}{r}0 \\
0 \\
43 \\
0\end{array}$ & $\begin{array}{l}2 \cdot 1 \\
1 \cdot 8\end{array}$ \\
\hline $\begin{array}{c}8 \\
\text { (V82) }\end{array}$ & M8 & 6 & $\begin{array}{l}\text { At operation: before valvotomy } \\
\text { : after valvotomy } \\
\text { Postop." catheter } \quad \text {.. } \quad .\end{array}$ & $\begin{array}{l}\because \\
\cdots \\
\cdots\end{array}$ & $\begin{array}{r}115 \\
92 \\
41 \\
\end{array}$ & $\begin{array}{r}100 \\
40 \\
25 \\
\end{array}$ & $\begin{array}{r}0 \\
32 \\
0 \\
\end{array}$ & $6 \cdot 6$ \\
\hline 9 & M15 & 3 & $\begin{array}{l}\text { Preop. catheter } \\
\text { At operation: before valvotomy } \\
\text { Postop." catheter after valvotomy (oper } \\
\text { Pos } \quad . .\end{array}$ & & $\begin{array}{r}146 \\
183 \\
75 \\
24 \\
\end{array}$ & $\begin{array}{r}129 \\
8 \\
0 \\
\end{array}$ & $\begin{array}{r}33 \\
42 \\
4 \\
\end{array}$ & 4.4 \\
\hline $\begin{array}{c}10 \\
\text { (V127) }\end{array}$ & M12 & 3 & $\begin{array}{l}\text { Preop. catheter } \\
\text { At operation: before valvotomy } \\
\text { " } \quad \text { : after valvotomy } \\
\text { \#" after infund. resect. } \\
\text { Postop." catheter } \quad . . \quad \text {.. }\end{array}$ & $\begin{array}{l}\because \\
\because \\
\cdots \\
\cdots\end{array}$ & $\begin{array}{r}123 \\
180 \\
110 \\
80 \\
25 \\
\end{array}$ & $\begin{array}{r}110 \\
164 \\
0 \\
0 \\
0 \\
\end{array}$ & $\begin{array}{r}0 \\
0 \\
92 \\
62 \\
0 \\
\end{array}$ & \\
\hline 11 & F12 & $1 \frac{3}{4}$ & $\begin{array}{l}\text { Preop. catheter } \\
\text { At operation: before valvotomy } \\
\text { Postop." catheter valuotomy } \\
\text { P.. }\end{array}$ & $\begin{array}{l}\because \\
\because \\
\cdots\end{array}$ & $\begin{array}{r}171 \\
166 \\
114 \\
49\end{array}$ & $\begin{array}{r}160 \\
148 \\
0 \\
0\end{array}$ & $\begin{array}{r}0 \\
0 \\
96 \\
27\end{array}$ & $\begin{array}{l}3 \cdot 7 \\
3 \cdot 6\end{array}$ \\
\hline
\end{tabular}

Valvotomy was by the closed transventricular technique except

in Case 9. Infundibular resection was performed in Case 10 only.

* V116 and similar numbers refer to the same cases as in the paper by Campbell (1959). 


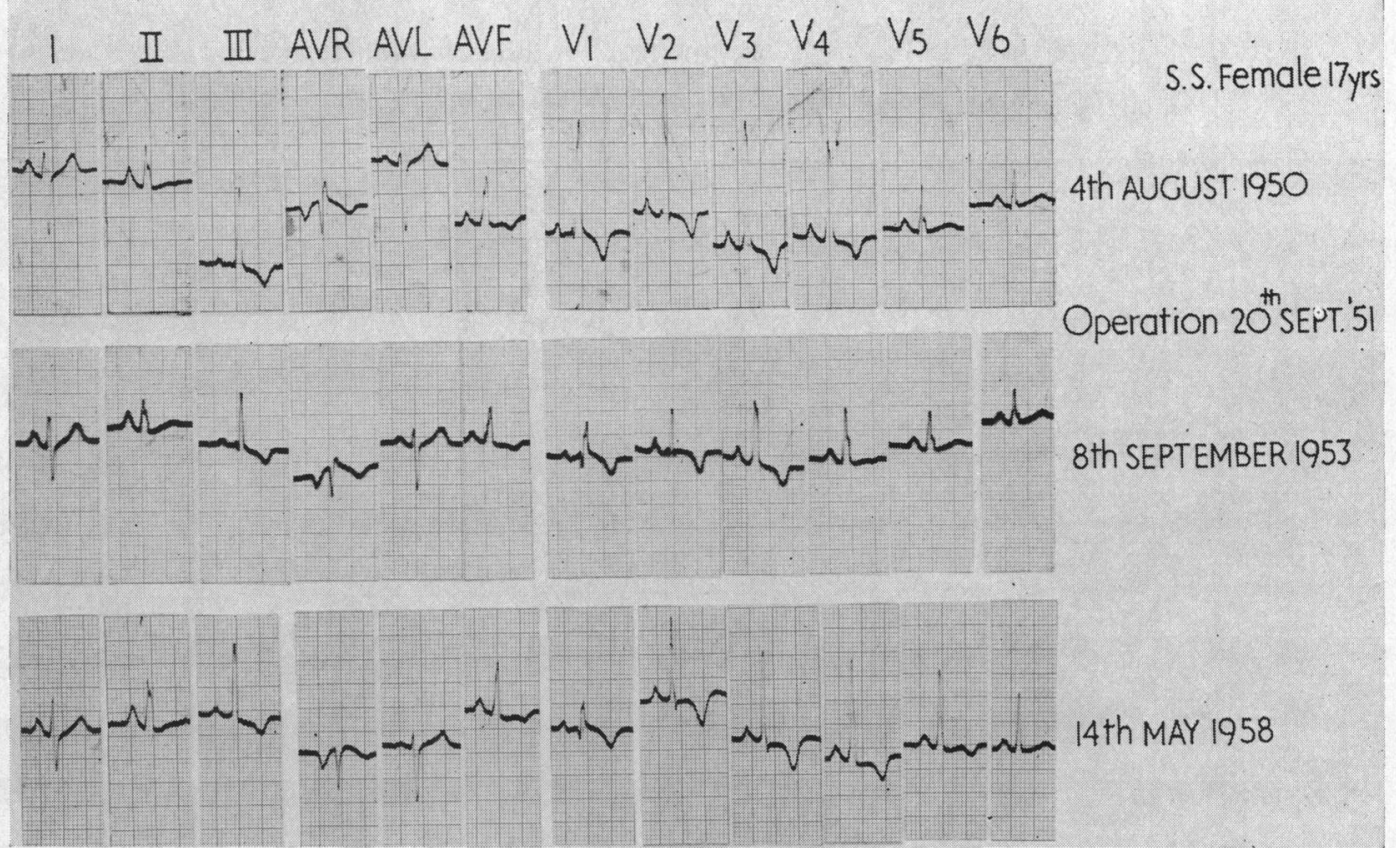

FIG. 4.-Electrocardiogram showing diminution, after valvotomy, of R-wave over right ventricle, without improvement of T-wave inversion, probably because of the production of pulmonary regurgitation. Case 7 .

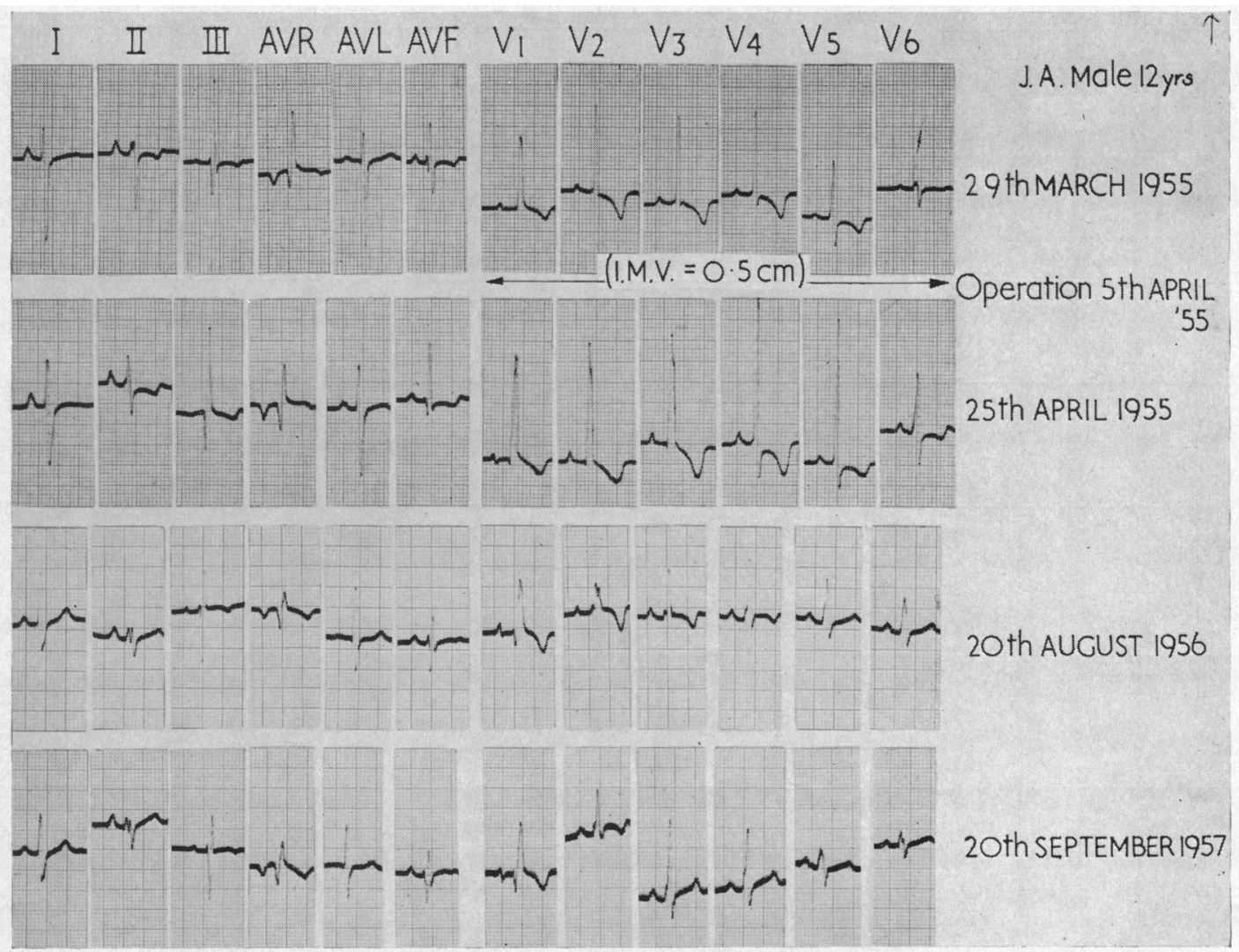

Fig. 5.-Electrocardiogram showing concurrent improvement, after valvotomy, of R-wave voltage and of T-wave inversion over the right ventricle. Case 10. 
C.TR\% Post P.V. qradient. - -mixed. o-I only. $x-V$ only.

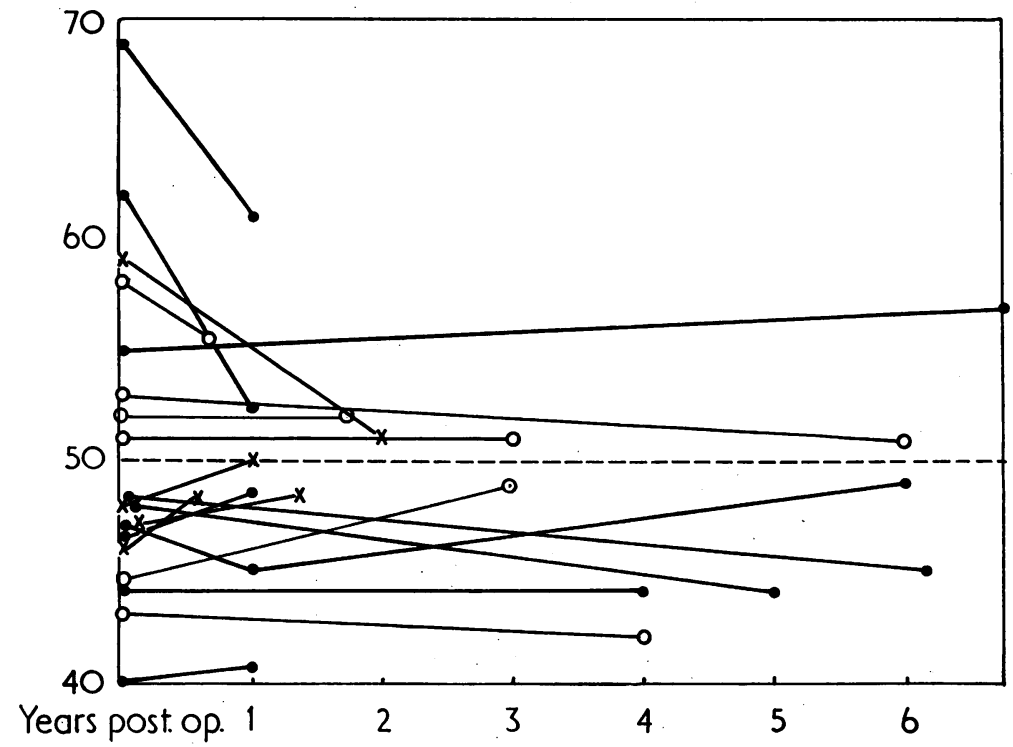

FIG. 6.-Cardiothoracic ratios at time of operation and at cardiac catheterization after operation.

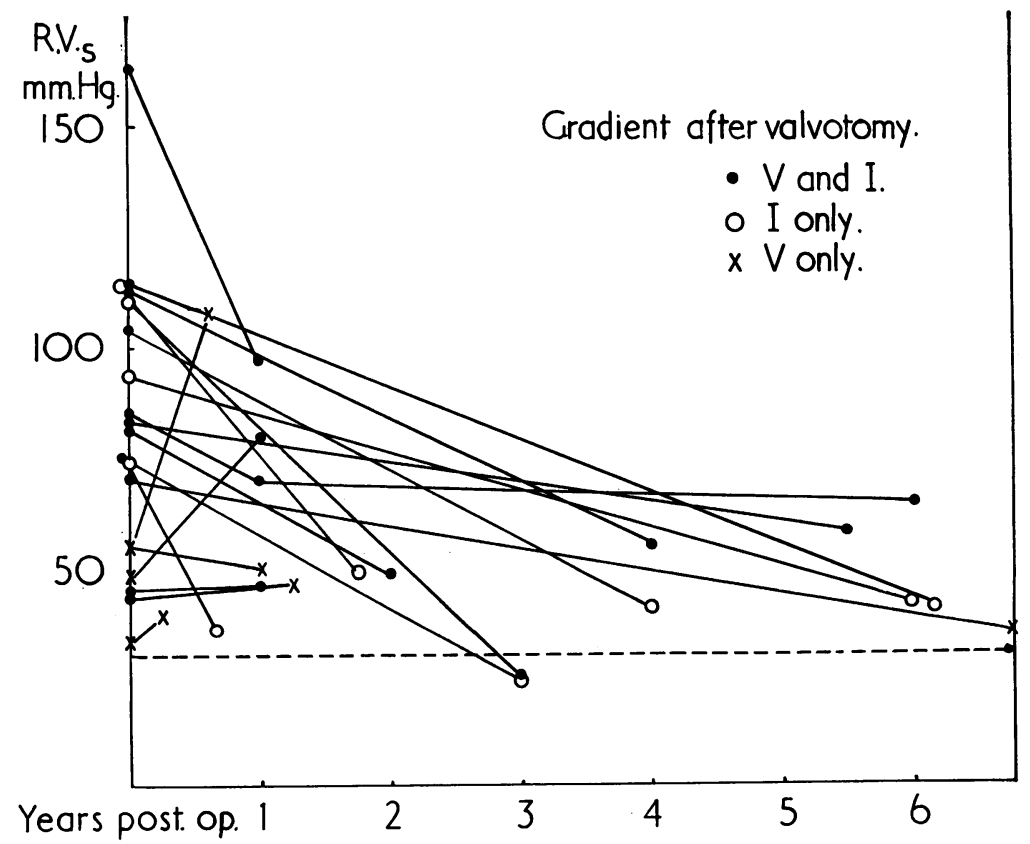

FIG. 7.-Right ventricular systolic pressures immediately after pulmonary valvotomy and at cardiac catheterization some time after operation. 
Studies on the cardiac output at rest and during exercise in these cases are continuing and will be reported. At the present time it can be said that resting cardiac output, which was low or low-normal before operation in all cases, has shown no consistent change. Further, the response to exercise was still abnormal in more than half of these cases, even when residual stenosis was very mild.

\section{Discussion}

Judged by the criterion of right venticular systolic pressure (Wood, 1956) at pre-operative cardiac catheterization there were no mild cases in this group. Of the fifty-five catheterized before operation, four were moderate and fifty-one were severe. There has been no lessening in the severity of cases offered for surgery over these years, which illustrates the point that relief of pulmonary stenosis is still generally recommended only when, by all criteria, it is severe.

The incidence of secondary infundibular stenosis in this series is rather higher than that reported by McGoon and Kirklin (1958). In patients who had undergone transventricular valvotomy they found infundibular stenosis, in addition, in 22 per cent of children and in 64 per cent of those aged fifteen years or more. The higher incidence $(77 \%)$ in our open as compared with our closed valvotomy cases $(51 \%$ ) may reflect a somewhat more complete valvotomy by the open technique. This would allow better right ventricular emptying and so favour the appearance of infundibular stenosis through closer apposition of the walls of the outflow tract in systole

In the present series a persistently raised right ventricular systolic pressure exceeding $100 \mathrm{~mm} . \mathrm{Hg}$ after the operation appeared to have prognostic significance. In the post-operative period it was associated with a high morbidity and mortality from systemic hypotension and right ventricular failure. Regarding the long-term prognosis, three out of eleven cases specifically studied to assess regression of infundibular stenosis showed incomplete regression. These were the only three in whom the operation had not reduced right ventricular systolic pressure to $100 \mathrm{~mm}$. or less. It is of interest that the same pressure was considered critical by Hosier et al. (1956), who studied the results of pulmonary valvotomy in 69 children, 17 of whom had cardiac catheterization before and after operation. They found that, in patients whose right ventricular systolic pressure was reduced below $100 \mathrm{~mm}$., even though it remained above $60 \mathrm{~mm}$., the heart showed a decrease in size and thereafter remained constant as the child grew. Thus, over a period of years, the cardiothoracic ratio returned to normal. In contrast, in three patients where it remained above $100 \mathrm{~mm}$. after operation, their hearts and chests grew proportionately, so that cardiac enlargement persisted in these cases. Similar observations were made regarding electrocardiographic improvement in the two groups.

Thus persistence, after pulmonary valvotomy, of a right ventricular pressure exceeding $100 \mathrm{~mm}$. may be suggested as an indication for infundibular resection since both the immediate and the remote prognosis appear to be adversely affected. It seems clear, however, that a wide resection is necessary for adequate relief of hypertrophic infundibular stenosis and to achieve this ventriculotomy is needed. This procedure in itself may well add to the hazards of the post-operative period and it remains to be seen at what level of right ventricular hypertension the risk of leaving this unrelieved comes to exceed the risk inherent in ventricular incision and muscle resection.

The finding of an abnormal response of the heart to exercise in more than half of the cases so far studied suggests irreversible myocardial damage, presumably resulting from the years of severe stenosis. It is in accordance with the macroscopic and histological finding of diffuse fibrosis of the right ventricular myocardium previously reported in such cases (Allanby and Campbell, 1949). Wood (1958) has suggested that a right ventricular systolic pressure of 50 or $60 \mathrm{~mm}$. $\mathrm{Hg}$ might now be taken to indicate valvotomy. Our findings lend support to a plea for operation upon milder cases than have hitherto been considered in need of relief and for earlier operation in severe cases.

\section{SUMMARY}

Seventy-five cases of pulmonary valvotomy, performed for pulmonary stenosis with closed ventricular septum, have been reviewed. 
Secondary infundibular stenosis, due to right ventricular hypertrophy, was found in 51 per cent following closed transventricular valvotomy and in 77 per cent after open valvotomy through the pulmonary artery.

A right ventricular systolic pressure exceeding $100 \mathrm{~mm} . \mathrm{Hg}$ after valvotomy appeared to affect adversely both the immediate post-operative and the long-term prognosis.

Regression of hypertrophic infundibular stenosis with the passage of time after valvotomy has been demonstrated. It appears that this may be incomplete when the right ventricular systolic pressure exceeds $100 \mathrm{~mm}$. $\mathrm{Hg}$ after valvotomy, but otherwise it is complete. The question of infundibular resection is discussed in the light of these findings

The response to exercise in some of these cases, even after virtually complete relief of stenosis was still abnormal. Fuller details of this will be reported later.

My thanks are due to Sir Russell Brock, whose keen interest in the long-term results of cardiac surgery and special interest in this complication of pulmonary valve stenosis prompted this investigation of his cases.

Many of these patients have been the subject of earlier follow-up reports by Dr. Maurice Campbell and Sir Russell Brock and I am grateful to them for allowing me to make this study of a particular aspect of these cases. To them and to Dr. Charles Baker I am indebted for continued encouragement and helpful criticism.

It is a pleasure to acknowledge the untiring and careful help of the technicians of the Cardiac Department and the co-operation of the Department of Medical Illustration.

\section{REFERENCES}

Allanby, K. D., and Campbell, M. (1949). Guy's Hosp. Rep., 98, 18.

Blount, S. G. Jr., van Elk, J., Balchum, O. J., and Swan, H. (1957). Circulation, 15, 814.

Brock, R. C. (1948). Brit. med. J., 1, 1121.

- (1955). Guy's Hosp. Rep., 104, 356.

- (1957). The Anatomy of Congenital Pulmonary Stenosis. Cassell, London.

- and Campbell, M. (1950). Brit. Heart J., 12, 377.

Campbell, M., and Brock, R. C. (1955). Brit. Heart J., 17, 229.

, (1959). Brit. Heart J., 21, 415.

Donald, K. W., and Christie, R. V. (1949). Clin. Sci., 8, 21.

Engle, M. A., Holswade, G. R., Goldberg, H. P., Lukas, D. S., and Glenn, F. (1958). Circulation, 17, 862.

Hosier, D. M., Pitts, J. L., and Taussig, H. B. (1956). Circulation, 14, 9.

Kirklin, J. W., Connolly, D. E., Ellis, F. H. Jr., Burchell, H. B., Edwards, J. E., and Wood, E. H. (1953). Circulation, 8, 849

Lillehei, C. W. (1958). New Eng. J. Med., 258, 1044.

McGoon, D. C., and Kirklin, J. W. (1958). Circulation, 17, 180.

Swan, H., Cleveland, H. C., Mueller, H., and Blount, S. G. Jr. (1954). J. thorac. Surg., 28, 504.

Wood, P. (1956). Diseases of the Heart and Circulation. 2nd ed. Eyre and Spottiswoode, London.

- (1958). Symposium on Congenital Heart Disease. Brit. Heart J., 20, 280. 